\title{
An Embryonic Journey of Musical Entrepreneurship with "The Captain,” Jorma Kaukonen, and His Co-Pilot, Vanessa
}

\author{
J. Michael Geringer ${ }^{1} \&$ Jeffrey Anderson ${ }^{1}$ \\ ${ }^{1}$ College of Business, Ohio University, Athens, Ohio, USA \\ Correspondence: J. Michael Geringer, College of Business-Center for International Business, Copeland Hall \\ 401A, Ohio University, Athens, Ohio 45701, USA. Tel: 1-740-593-2036. E-mail: geringer@ ohio.edu
}

Received: July 23, 2014

Accepted: August 13, 2014

Online Published: September 25, 2014

doi:10.5539/ibr.v7n10p101

URL: http://dx.doi.org/10.5539/ibr.v7n10p101

\begin{abstract}
The music business is a case study in how macro-environmental factors can radically transform an industry. Developments such as digital production and distribution, coupled with social media, crowdfunding, and changing consumer preferences, have dramatically transformed the business model for the recorded music industry in recent years and spurred the development of entrepreneurial business models to enable musicians to survive in their changing environment. As a solo artist and founding member of the musical groups Jefferson Airplane and Hot Tuna, Rock and Roll Hall of Fame musician Jorma ("The Captain") Kaukonen has recorded albums for major labels such as RCA, Sony, and Columbia, as well as independent labels such as Relix and Red House Records. In this interview, Jorma and his wife and business manager, Vanessa Kaukonen, discuss their experiences as musical entrepreneurs in the digital age, including their founding of the unique Fur Peace Ranch guitar camp in the hills of Appalachia. The entrepreneurial business undertakings of the Kaukonens highlight the potential for entrepreneurial musicians to develop innovative and sustainable business models for surviving in this new world of music.
\end{abstract}

Keywords: entrepreneur, music entrepreneurship, business model, music industry, musician, innovation, Jorma Kaukonen

\section{Introduction}

The music business is a case study in how macro-environmental factors can radically transform an industry. Developments such as digital production and distribution, coupled with social media, crowdfunding, and changing consumer preferences, have dramatically transformed the business model for the recorded music industry in recent years and spurred the development of entrepreneurial business models to enable musicians to survive in their changing environment. As a solo artist and founding member of the Jefferson Airplane and Hot Tuna, Jorma Kaukonen ("The Captain") has recorded albums for major labels such as RCA, Sony, and Columbia, as well as independent labels such as Relix and Red House Records. In this interview, Rock and Roll Hall of Fame musician Jorma Kaukonen and his wife and business manager, Vanessa Kaukonen, discuss their experiences as musical entrepreneurs in the digital age, including their founding of the unique Fur Peace Ranch guitar camp in the hills of Appalachia. The entrepreneurial business undertakings of the Kaukonens highlight the potential for entrepreneurial musicians to develop innovative and sustainable business models for surviving in this new world of music.

The next section provides a brief discussion of the backgrounds of the interviewees, Jorma and Vanessa Kaukonen. An overview of the recorded music industry and structural changes that have transformed this business is then provided, in order to highlight the context in which the Kaukonens' entrepreneurial music endeavors have been undertaken. We then provide the transcript of the interview with the Kaukonens. The interview itself was conducted on-site at the Kaukonens' entrepreneurial Fur Peace Ranch, which is located in the rural foothills of Darwin, Ohio. Questions were developed by the authors in advance and shared with the Kaukonens prior to the interview, although further exploration of key topics was initiated as the interview proceeded. The interview was recorded both digitally and on tape, transcribed into Microsoft Word, and then a word-by-word comparison of the printed and audio versions was conducted in order to ensure completeness. The resulting transcript was reviewed by the interviewees to ensure accuracy. Portions of the interview transcript were subsequently edited in order to provide a more concise presentation of key issues relevant to the musical 
entrepreneurship activities of the Kaukonens, and this edited transcript was again reviewed by the Kaukonens to ensure that no inaccurate or misleading comments resulted. Interview questions are preceded by "INT:" and the corresponding responses are indicated as coming from either Jorma or Vanessa.

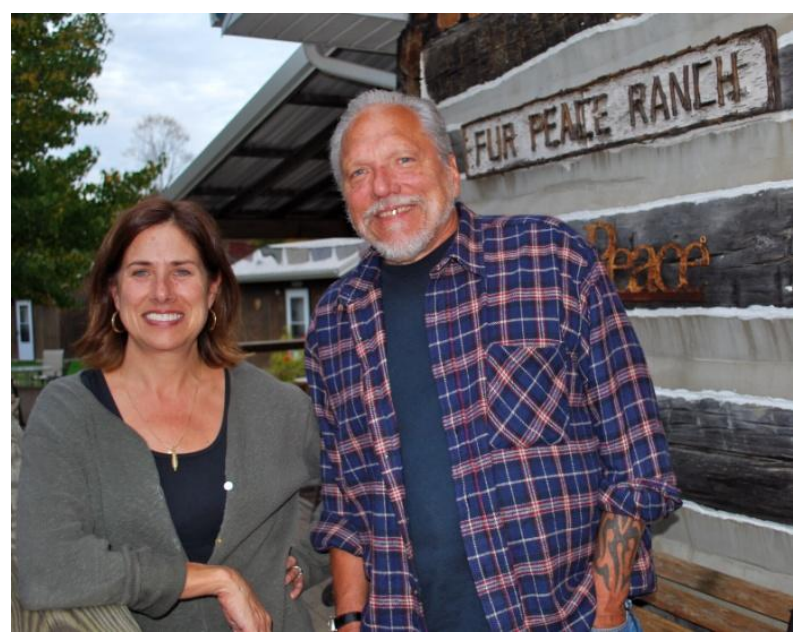

Figure 1. Vanessa and Jorma Kaukonen in front of the Fur Peace Ranch main cabin

\section{Background on the Interviewees: Jorma and Vanessa Kaukonen}

\subsection{Biography of Jorma Kaukonen}

Jorma Kaukonen is a Grammy-nominated finger-style guitarist and a 1996 inductee into the Rock and Roll Hall of Fame. His career in music has spanned over 50 years and he is regarded as a leading practitioner and interpreter of American roots music. Born December 23, 1940, to a Finnish-American father and an American-born Russian Jewish mother, Jorma was raised in the Washington D.C. area. As a teenager, he learned to play guitar and formed a band named The Triumphs with future Jefferson Airplane bassist Jack Casady. While studying in Antioch College in Ohio, Jorma met Ian Buchanan, who introduced him to the elaborate finger-style fretwork of the Reverend Gary Davis. Later, during a college work-study program in New York, Jorma was introduced to Rev. Davis and many of the city's skilled folk-blues-bluegrass players.

Jorma moved to the San Francisco Bay Area in 1962 and enrolled in Santa Clara University, graduating with a bachelor's degree in Sociology. He earned money by teaching guitar and playing in coffee houses, first as an accompanist to a young Janis Joplin and later as a solo performer. He was a founding member of the Jefferson Airplane, which emerged from the Haight-Ashbury culture of San Francisco to become one of the seminal rock bands of the 1960s. Anxious to play more, he and Airplane bassist Jack Casady formed the duo Hot Tuna as a side project. Hot Tuna survived the subsequent demise of the Airplane and the duo continues to perform to this day. As a solo musician and member of the Jefferson Airplane and Hot Tuna bands, Jorma has released more than 50 albums and played as a guest on dozens of projects for other artists.

Jorma's song, “Embryonic Journey," first appeared on Jefferson Airplane's Surrealistic Pillow album in 1966. This song was subsequently incorporated in a number of movies, television shows, and commercials, and it has become one of his signature performances during live shows.

\subsection{Biography of Vanessa Kaukonen}

Vanessa Lillian Kaukonen is the CEO and co-owner of the Fur Peace Ranch in Meigs County, near the community of Darwin, Ohio. Vanessa earned a degree in Civil Engineering and Design from Hartford State Technical College before moving to Key West, Florida, to work on the design team for the Truman Annex. Before opening the Fur Peace Ranch in 1998, she managed several national recording artists and still works to manage her husband Jorma's career. Vanessa used her civil engineering and design experience to conceptualize and build the entrepreneurial Fur Peace Ranch guitar camp. 


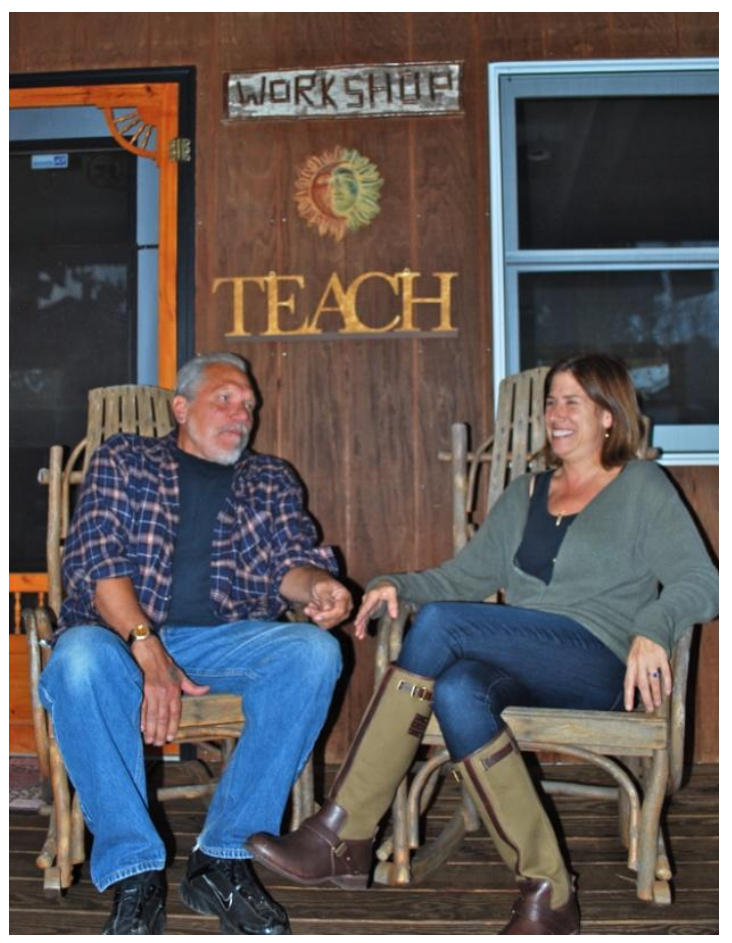

Figure 2. Vanessa and Jorma Kaukonen in front of the Guitar Workshop at Fur Peace Ranch

\section{Background on the Recorded Music Industry and Structural Changes that Have Transformed this Business}

Recorded music sales in the U.S. peaked in 2000 when consumers purchased 943 million music CDs (The Economist, 2007). Digital distribution of music grew exponentially after 1999, when Napster introduced their revolutionary peer-to-peer service, which enabled people to share MP3 files, including copyrighted music, via a user-friendly interface. Although Napster was shut down by court order in 2001, due to concerns with copyright violations, the genie was out of the bottle and consumer migration to digital distribution of music continued its seemingly inexorable push forward. In 2003, Apple opened their iTunes music store, selling single songs for $\$ 0.99$ apiece. In the next decade, annual recorded music sales in the U.S. plummeted nearly 40 percent, from $\$ 11.3$ billion to $\$ 7.1$ billion (Covert, 2013).

In the decades up to 1998, most records with substantial cultural impact were recorded in professional recording studios and distributed on LPs, tapes, and subsequently on compact discs by record labels, particularly those owned by the major music companies. The introduction of the Pro Tools digital audio workstation software in 1991 enabled individuals to record, mix and master professional quality music. When Pro Tools enabled 24-bit, 48 track engineering capability in 1997, entry barriers to the recording and engineering sector of the music industry experienced a rapid decline, which was manifested in a mass migration from the traditional conventional studio technology to lower cost alternatives, including inexpensive home studios or even recording and editing on a laptop computer.

Ironically, while total recorded music industry revenue is down appreciably, there are indications that consumers - particularly youth - are listening to music more than ever. What has changed is how they access and consume this music. In addition to continued access and downloading through a variety of peer-to-peer channels, the emergence of social listening sites like Pandora and Spotify have enabled consumers to pay less for accessing their music (albeit, sometimes in exchange for alternatives such as providing personal data that can be used for targeted advertisements) (Berklee College of Music, 2013).

The economic consequences of these changes have been profound for musicians. In 2000, professional musicians earned two-thirds of their income from pre-recorded music, via record labels, with the remaining one-third coming from concert tours, merchandise and endorsements. By 2007, those proportions had flipped. According to trade magazine Pollstar, concert sales in 2013 hit a record $\$ 5.1$ billion, compared to the 2000 total of $\$ 1.7$ billion (Pollstar, 2014). 
Given the changes in the industry, there have never been better opportunities - and need - for musical entrepreneurs and the creation of new business models for the music industry. Digital distribution and recording have created low entry costs for the music industry. Armed with a laptop and a website, with little or no cash, a musician can make an impact on culture in ways that were impossible before. Many institutions of higher learning have recognized the opportunity to develop musical entrepreneurs and several have begun to offer course tracks and certificate programs, including the Berklee College of Music, which announced the launch of the Berklee Institute for Creative Entrepreneurship in 2014 (Balkin, 2014).

\section{Interview with Jorma and Vanessa Kaukonen on Entrepreneurial Responses to Deal with the Transformation of the Music Industry}

\section{INT: Did you ever want to be anything besides a musician?}

Jorma: I started playing music when I was 14 or 15 years old. I don't think I ever thought of it as a career or anything, although Jack (Casady) and I were in high school bands and we did get paid. The reality is that I really loved it. My metaphor for this would be to quote Chris Smither, "I fell into it as a kid and I never fell out of it." That's pretty much what happened in my case.

\section{INT: Were there ever any times where you thought maybe you should try something else?}

Jorma: No! No, I realized I was horribly underqualified for anything else. I might've even been underqualified to be a musician, too! Laughter. But I was really underqualified for anything that involved punching a time clock. I mean, I've had straight jobs and stuff. I worked for the government. I even took the civil service exam and, naah, it wasn't for me.

INT: So you grew up in the historic era of music. What do you see as being different about the business model today?

Jorma: Well, I'm sure there are a lot of different ways to look at this. If you think about when we came up, it was an era dominated by the major labels and when the minor labels were only doing folk stuff and reissues. You couldn't make a recording without having a deal because the studios were owned by the record companies and you couldn't afford to own the equipment yourself. Now we can do all the stuff ourselves, so it's a very different situation.

I was lucky to be in a band that had three great singers and they wrote great songs, in an era when the record companies were looking for that. But I think in some respects that bands such as the Jefferson Airplane were the transition between the old school and what happened later on, because we didn't toe the line like the labels wanted us to. The labels wanted us to use their producers and their studios and their studio musicians and ultimately get people to write songs in whatever mold was popular at the time. So we were fortunate to get a record deal back then, because in my opinion they thought that we fit into their model. They didn't realize that wasn't what we were at all! We pretty much did whatever we wanted to do. We got real lucky with the album Surrealistic Pillow, because that was really a commercial album. I don't think we set out to do that, because none of us were professional songwriters. In fact, before joining the Airplane, only two guys in the band, Spencer (Dryden) and Jack (Casady), had actually played in bands professionally! The rest of us were folkies. So we didn't have that thing like many of the LA guys had, where we needed a song with the right sound, where we needed a producer, and where it was "you do this and you do that" in order to make things happen. We foolishly thought we could do it all ourselves. And, as it turned out, we could!

Another thing is that we also got to work with some incredibly talented producers. Rick Jarrard, the guy who produced Surrealistic Pillow, realized who we were and so he had Jerry Garcia coproduce it. Even though he's not credited as a co-producer, Jerry was there and Rick realized that we would listen to him. As a result, it's a professionally produced album. Later on, we worked with Al Schmitt, a guy who'd done all of this Motown stuff. He somehow managed, out of the chaos that was us as the Airplane, to pull things together. In any case, we had those big hits. That's why we got into the Rock and Roll Hall of Fame, based on two hit songs: Somebody to Love and White Rabbit. And then we got to make a bunch of records that were okay. But we were never a hit-making machine like the Eagles, who were the epitome of that whole thing. Whatever the Eagles' formula was, it really worked. And then, as time went on, I guess that the technology really spelled the death knell for the major labels, because now anyone can do it.

\section{INT: How do you make the major labels' business model work in this new world of music?}

Vanessa: Marketing goes out over Twitter and Facebook now. That's the major marketing push these days. It's not the Rolling Stone, it's not Billboard. It's about who you've got out on the street. 
Jorma: It's funny you asked me this question, because I'm really sort of old school about it. I'm still with kind of a large independent label called Red House, both my band Hot Tuna and myself individually. And before that, I did the album Blue Country Heart for Columbia Records, which was a major label. Had I not done that, I probably wouldn't have gotten a Grammy nomination, because it's still a bit of an old boys network. Anyway, when I got the deal with Columbia, my producer friend who got me the deal said, "Why do you want to do this? You could do it yourself, just like what the kids are doing these days." I said to him, "I want to do it because of the cachet." That's why I did that, and I still feel pretty much the same way about Red House, because it really takes a burden off me. We've been around for so long that our stuff kind of moves in its own sort of ponderous but somewhat predictable way, as opposed to really having to go out and bust your ass. Of course, we've got Twitter and Facebook and all that kind of stuff too, but that coupled with the fact that we've been around for so long makes things work for us at our level. A lot of the success stories that you see happening for younger artists, it is remarkable how they've thrown their hat in the ring and it's come up roses for them. They know how to do all this stuff and people like what they do. So I think in some respects, it's a blessing for everybody that the majors are not major anymore, although they still seem to be out there doing some of it. Can you even buy a single anymore? I mean, who knows. We cut singles, back in the day.

\section{INT: Do the changes make it easier for musicians to be successful, having all the change in technology and} venues?

Vanessa: I have a seven-year-old daughter, and the music that I listen to is the Hits One station on Sirius radio. When I can't listen to any more Bruno Mars, I go over to the Pulse station and they are marketing that in a completely different way. They're doing it through younger DJs. I listen to them, and they sound mature, but they are in their early 20s. So their language is different. I mean, what the heck is "twerky"? I mean, I think it fits for this generation, it connects with them. As Jorma said, with what we have today in terms of technology and everything, anybody with a little talent doesn't need a major label behind them to be successful.

Jorma: What Vanessa is talking about, with these hit channels on Sirius XM, when I listen to that stuff, the words mean nothing to me, they are from another universe. But when I hear the music, I hear disco. This is disco. So the music machine is still alive and well because it's not cheap to do this new stuff. They say all of these guys with a computer workstation know how to do this in their living room while they're watching the news or something, but I'll bet not. If you listen to the sound, a lot of that stuff is very skillfully produced.

\section{INT: You still need talent to be successful in the music industry, don't you?}

Jorma: Right, the machines are not going to do it for you. They are just instruments. In the beginning, I sort of looked at things like rap a bit askance. But when you listen to it, it's like when you listen to blues. There are a lot of different blues formats. Or if you listen to reggae, it's another format to convey your message. The same is true with rap. It's just another format to convey a message. The format I prefer has a lot more live instruments in it. But it's the same thing.

Vanessa: The wall in our Psylodelic Gallery, all of those quotes? That was at a time when people were shouting out, they were demanding to be heard for whatever reason, political or whatever. The stuff that I'm listening to on stations these days? They are also demanding to be heard. Now, does it have any substance to it? I even made a joke up on stage about Bruno Mars and that song Gorilla. It's all sex and getting messed up on alcohol and drugs. That's what that song is all about. "I got a body full of liquor and a cocaine kicker and I'm feeling 30 feet tall." So, okay, we know what you're doing tonight! But the language of a lot of the stuff that these guys are singing is so disrespectful, especially to women, and I don't want my daughter listening to that. The beat was so good, I initially thought, "Oh, my God! This is a great song!" Then I heard the words and I went, "Oh, my God! This is NOT a great song!" I don't want any daughter of mine thinking, whatever she does when she leaves the house when she's 18 years old or whatever, that having a belly full of liquor and a bunch of blow and letting some guy have his way with her - because he says he has a fistful of her hair and he's basically going to screw the heck out of her. I'm shocked! Is that what they are demanding to be heard?

Jorma: He's playing to his audience. (laughter) But I have to go on record and say this is nothing new. I remember an album that came out in the late 1960s, by Johnny and Shuggie Otis under the name of Snatch and the Poontangs, it makes this stuff look like kindergarten. That was all jailhouse stuff. So it's nothing new. Sex has been around a long time. Drugs have been around a long time. If you listen to the stuff that was on the radio back when I was a kid in DC, like Champion Jack Dupre singing, "I can't kick this habit, man, this junk is killing me," that was on popular radio. So this is nothing new. But if you are talking about content and messages, as an older guy, I'm not saying that things were better when I was younger. I'm not saying the new stuff is bad music. But I don't see any relevance, any social relevance, in most of the music that I am hearing in the popular realm. 
You know, when Jellyroll did all those recordings for the Library of Congress, his original lyrics aren't on the Library of Congress recordings, because in that era in the United States we censored for sex, while in Europe they censored for violence. So all of the unexpurgated versions came out on discs from Europe, which is where I heard those tunes. There's nothing new under the sun.

Table 1. Overview of the Fur Peach Ranch

The Fur Peach Ranch (FPR), which began operation in 1998, is a seasonal music school located outside the community of Darwin in the Appalachian foothills of southeast Ohio. Conceived by Jorma and Vanessa Kaukonen as "a ranch that grows guitar players," the Fur Peace Ranch is not a fantasy camp. Students travel from around the world to learn from master performers like G.E. Smith, David Bromberg and Tommy Emanuel, with training delivered during a Friday-to-Monday schedule. While finger-style guitar is the popular format and Jorma is the most sought after teacher at FPR, the Ranch also offers instruction on a host of other instruments, from bass guitar to lap steel guitar, mandolin, percussion, vocals and songwriting.

The Fur Peace Ranch campus sits on 119 acres of forested rural farmland in southeast Ohio and includes 22 buildings, with a 200-seat performance hall, a full service restaurant, Ranch general store, and the Psylodelic Gallery. FPR students sleep in cozy two-person bunkhouses and dine on five-star quality meals in the camp's restaurant. The sounds of guitar fill the air well into the evening as students get together to practice and jam between and after attending instructional workshops. The camp experience includes a Saturday concert, usually performed by one of the camp instructors and with seating available to attendees from both the local community and hundreds of miles away. A Sunday student concert gives students an opportunity to show what they've learned during their camp experience, with Jorma typically working as a stage hand.

The value of the student experience at FPR is best measured by the level of repeat business. Labeled as "repeat offenders" by Jorma and Vanessa, more than 3,000 students have taken multiple workshops at the ranch; some have attended as many as 30 times.

INT: So we do have something new under the sun, Fur Peace Ranch, which is kind of unique as a concept. Can you give us an indication of where this idea originated and how it evolved over time?

Vanessa: We were living in Woodstock, New York, and Jorma gets a call from a friend who says he's selling his property in Ohio. God rest his soul, this friend was one of the original outlaws of Meigs County, Ohio. Jorma had known him for years, outside of the whole music scene.

Jorma: I had known him from South Florida in the early 1960s, when his motto was, "Drive the boat or fly the plane."

Vanessa: So he calls Jorma. I had never met him before, but I could hear him bellowing over the phone, "Jorma, I've got this land for sale."

Jorma: He talked really loud because on one of his flights to South America, he lost 10,000 feet of altitude in a matter of seconds and it just popped his eardrums. So he spoke really loud.

Vanessa: So I'm whispering to Jorma, "Hang the phone up! Are you crazy?" We'd only been married a couple of years and I'm like, "Ohio?" And Jorma says, "I'm going to go and take a look at it." So he goes and comes back three days later with a deed to some land in Ohio. I'm like, "We will never speak of this again, don't tell anybody we own land there!" Then, a year and a half later, we're driving to Ohio to look at the property and I'm crying the whole way here. I'm like, "What happened?" I was working in New York City, taking the train, and I was kind of loving life. Now I'm moving to ... Middle Earth!

Jorma: I'll never forget sitting around the campfire here on the ranch during our first visit. A copperhead snake came out and I shot his head off with a 12-gauge shotgun. It was a great night! Laughter

Vanessa: He brought me to see the land and when I saw the snake, I said, "I'm going back to New York!" I hopped in the car and said, "I'll see you! Goodbye!" And I went back. Anyway, at that point it was a reality, we're moving here to the property. So we have this big blowout party in Woodstock, a big "We're moving to Ohio" party. Our friend, Chuck Fidel, had just come from the author T. Boyle's place. T. Boyle was up at Saratoga at the time, finishing the Road to Wellville or something. We told Chuck that we had bought land and we were moving to southeastern Ohio. Chuck said to Jorma, "Man, that's a fur piece from anywhere," and everybody chuckles and the laughter just went on and on. When the laughter finally stopped, I looked at my sister, Ginger, and said, "Fur Peace Ranch, where we're going to grow guitar players!"

Jorma: So before we even moved here, we had T-shirts and stationery. That's true!

Vanessa: We moved here and did nothing for a year. The land was here and there was a little dilapidated A-frame 
that became Jorma's old recording studio. This place was rough, so we didn't move onto the property itself. Instead, we found a farm 8 miles down the road, with this tiny little farmhouse. And I'm like, "I'm going to die here, I'm going to die here." Then a year and a half later, maybe two years later, my sister was here, living and working with me, and I said to her, "What happened, Ginger? What happened to that idea? I know we joked about it back then, but we were going to grow guitar players!"

I was a civil engineer in another life, that's what I had done, and I wondered where to start. So Ginger and I took Tony Robbins' 30-day Personal Power course and we did everything that he laid out for 30 days. While we were doing all that stuff, we were building our idea for this school, for this ranch where we were going to grow guitar players. When it was all over, I had a set of renderings and I had the business plan three-quarters of the way done. Ginger had created the schedule, the original schedule that we stick to until this day. We contacted dietitians and other professionals to see what was the optimum amount of time that a person can just sit and take a crash course in anything. When do they have to eat, when do they have to take a break, what are the health benefits, and so forth?

Jorma: I don't know anything about any of that stuff. I would have been sitting on a bale of hay with my guitar. laughter

Vanessa: So we said, "Okay, if we're going to do this, what are we going to do? Workshops from Monday through Friday?" We decided no, because how are we going to get people to leave their jobs? We'll do it Friday through Monday. People are more apt to take a weekend off. So we stuck to that principle and to the schedule.

Not having built anything yet, I took this whole proposal package to my accountant and he told me, "Don't use any of your own money." I said, "But I have the money!" And he said, "Don't use your own money." I remembered one of the things that Tony Robbins said, "If you are going to lose, lose big. And don't use your own money." That's what he said. What's the worst that can happen? You fail and you start over. So I said okay and met with my local banker. At the time, I had just gotten a tattoo and I had an eyebrow ring. There was nothing I was going to do about the eyebrow ring, but the tattoo I tried to hide. It was a hot summer day. I stood out on that hill over there on the Ranch and I said we're going to build this and we're going to do that. He just looked at me like I had two heads, but he gave me the loan! He's a totally conservative guy, and I'm not conservative, but he called me in a week and said, "I'm going to give you the loan." They weren't going to give me all the money, though. They gave me like two-thirds of what I needed. So he believed in me, but he didn't believe in me that much! Laughter. Years later, I asked him what was it that convinced him to fund us. And he said, "I believed in you."

So we built it. Four months after we got our loan, we pounded our first nail. That was in August of 1997. The Ranch itself opened in April of 1998, without screen doors on the buildings and without outside lights because we ran out of money. There was mud everywhere. I remember freaking out because we had our first class coming and there was mud everywhere. Then a local landscaper brought over a bunch of hay to spread over the mud. One of Jorma's old guitar players from Hot Tuna, Michael Falzarano, was here and he said, "Vanessa, so what if there's hay on the ground? Nobody's ever been here before, so they don't know what the place is supposed to look like!"

I had no money for advertising. I had spent the entire budget building the place, so we shelled out some of our own money. I took those renderings I had made, along with the story, and I made a hand bound book. I made 5,000 copies for my first run, and then I made another 5,000. Jorma was doing the Further Festival at the time, so I put the books out in the audiences and at the merchandise table. When a performance was over, if I saw books on the ground then I would grab them and re-use them at the next show. That's how I got my students the first year. Weird marketing, but I had no money left.

We were going to grow guitar players. I actually had the idea that we would use some of the wood from the trees here at the Ranch and have a guitar building class as one of our workshop offerings. But that never happened, because we couldn't sell that class.

Jorma: And that's the story of the Fur Peace Ranch. (laughter).

\section{INT: How close was the reality to the original concept for the Ranch?}

Jorma: You know, you can make plans, but that doesn't mean you can determine the outcome. It's grown in such an amazing way that we could never have envisioned in a million years when we first started out.

Vanessa: The community that we wanted to have in any one given weekend is what we envisioned originally. How it would grow, from April 1998 until now-going into our 17th season-I'll use a term that business owners aren't allowed to use: it's just been magical. You've been here, you know what I'm talking about, so I don't have 
to try to explain what it's like. Yet something happens when somebody comes to the Ranch and they've never been here before. We have a $97 \%$ return rate among our attendees, which keeps our workshops full, but it still happens for new participants if they are able to get in. When they pull up that driveway and park their car, they're scared to death. But when they get out of their car and Jorma's there to greet them ...

Jorma: It's one of those things that's really tough to verbalize, you know? People want to know what happens at the Fur Peace Ranch. We say, well, we have the instructors, and we have the radio show, and now we have the Psylodelic Gallery and all this stuff. We do have all of those things and we also have great food and everything. But the nature and depth of the community that becomes engendered over time, that's hard to quantify and when you try to talk about it, it sounds sappy. It doesn't print well. But it's true, that's what happens.

Vanessa: Our students get here on Friday afternoon and by Friday night and Saturday morning at breakfast, lifelong friends have been made. Bonds have been formed, and I really didn't see that. I couldn't write that in a business plan. So that's what I mean when I say that it's been beyond my wildest expectations. You know, we're really good at customer service. I don't think anybody does customer service better than we do. But the other stuff, you get all of these like-minded souls together and something magical happens. I still can't tell you the formula, but I think part of it is customer service. We kind of defuse all the tension, all the apprehension about, "I'm going to learn from Jorma!" It's like, "Come into our home."

Jorma: Yes, it's really interesting how it all happens. Earlier we were talking about the major labels and the star system and all of that kind of stuff. I won't say that I wasn't a bit starstruck by myself when we were young, because I'm sure we all were horribly obnoxious. Laughter. Yet, if you're lucky enough to stay in the business long enough, you realize what a blessing it is that you're actually able to do this. I think I would have done it anyway. But like I tell my son, if you're lucky enough to find something that sets you on fire, it doesn't get any better. If you can actually make a living at it, then it REALLY doesn't get any better. (laughter) Anyway, to make a long story short, it's just another gig. It's a lot more fun than digging ditches, unless you like to dig ditches. But it's just a job.

As a teacher, one of my things is to make the process of learning unintimidating. This presupposes that we knock down any of the barriers that might suggest that I - or any of the teachers or artists or anybody else - am doing something that the students couldn't do themselves if given the opportunity. Some people are better at it than others, of course, but I believe that anybody can do it. It's not like when I was learning to play! The generation that came before me, from the folk-blues world, the whole attitude of most of them was, "You can't learn to do this. You have to be really special to do this." That's just not true. The only thing that's special, that requires being special, is devoting a lot of time to doing it, loving it so much that you take the time to really learn how to do it. If you do that, you're going to learn it. What that did in my case, is that it presupposes that you don't go to class as much as you should. Laughter. So there's a trade-off here, which comes when your report card arrives. But all things considered, at the end of the day, things have worked out okay for me.

INT: So the Fur Peace Ranch guitar workshops are only one part of your portfolio, if you want to look at it that way. How do the workshops contribute to, and draw from, the other things that you are doing? Because in addition to the workshops, you've also got the performance hall, the Fur Peace Ranch general store, the Psylodelic Gallery, you still tour nationally and internationally, and you have many other activities you are involved with.

Jorma: I'm going to pass this one off to Vanessa, because she's really the brains behind the system. But before I do, if you think about the Psylodelic Gallery, or the performance area, or the teaching, or all of this kind of stuff that we're doing, in a way it's all the same thing because it's all culturally related. It really has to do with a profound love that I have for this music. Of course, not everybody plays the same stuff that I do, but I have this profound love for the large basket of musical categories that they have labeled as Americana, music that in many respects is timeless. The good stuff is timeless. I mean, it can be from 1930 or it can be from yesterday. That's part of the Psylodelic Gallery, that's part of the performance area, part of our workshops, or part of people just sitting around talking and playing music.

A lot of it also has to do with the relevance of the music. When I was coming up in the 60s, or even when I was a kid in the 50s, I was struck by the incredible relevance to the real world that so much of this music had. I mean, does anyone write protest songs today? Probably, but I'm not aware of very many of them. Billy Bragg, absolutely. But back then, when the music was coming out, you'd listen to the songs for the message they contained. Music from folks like Pete Seeger, a great, great man in my opinion, or a lot of the black blues guys that also got involved in writing topical songs, or Joan Baez, or the many other topical folk singers. Then, when the folk and rock bands started coming out in the 60s - I'm not talking about the "hits mill" guys but the guys that 
were actually writing songs that had relevance - when people, myself included, could hardly wait for the next album to come out to discover what they were saying, what was going on. Of course, we had an environment which nurtured that sort of thing. The issues were so much simpler then than they are today. You were either pro-Vietnam or you were anti-Vietnam. We weren't talking about a government shutdown or raising the debt limit or that kind of stuff. It was really much simpler. But everybody was into the issues of the day. You couldn't have a conversation with somebody without talking about current events in some way. Most of the audience at that time tended to be anti-establishment, so it was interesting. One wonders, for example, whether the Delmore Brothers or Jimmy Rogers or a lot of those guys were writing protest songs or whether they were just acting as some sort of gazette for what was happening at the time. Current events. Woody Guthrie and so forth, just telling stories about what was happening in the world. Whereas, for today, what rhymes with sequester? Sylvester? Laughter.

Vanessa: There's a thread that connects everything that Jorma does. For us, the thread is apparent in the most obvious way, but others may say that we've got so much going on. Yes, we acknowledge that we have a lot going on and sometimes it feels that we have too much going on. But right now we can't have the Psylodelic Gallery without the Ranch, and we can't have the shows without Jorma's involvement, and we can't get the word out unless Jorma tours. So we just have this constant flow of activities that fit well together.

\section{INT: What are the roles of the two of you in this process?}

Jorma: We're really great partners because Vanessa is an organizational maven. I can organize something if I am taking something apart and having to put it back together again. Thanks to YouTube, that's become a lot easier! Laughter I provide the creative energy that people see, and Vanessa provides the organized creative energy that makes things work. So when someone asks me whether I would like to do something, I say, "Look, I'll agree to anything, but if you really want it to happen, you'd better call Vanessa." She's the one that makes things happen. Really, what we do is complex, but the idea behind it all is very simple and Vanessa is the one with the vision to make it happen.

Vanessa: In some sense, I am your muse.

Jorma: No question about it.

Vanessa: Some of our marital "discussions," we don't call them fights, have created great songs. In the middle of a discussion, sometimes I'll say, "That's a really great line for a song!" Jorma's song Heart Temporary came from a discussion about Jorma being a better man and making things work better between us and his son Zach. We had a discussion and I had to make myself heard.

Jorma: I let her make herself heard. Then I went out to my studio and wrote the song.

Vanessa: And it's a great song! We complement each other in the finest way, I think. But Jorma is a realist. Not that I'm not, but ...

Jorma: Well, a classic example is when we built the theater. She wanted to build a 400 -seat theater. I tour for a living, you know, so sometimes it's a full house and sometimes it isn't. We don't promote for a living, so it's better to be turning people away than to have a half empty house. Four hundred people is a lot of people, and Fur Peace Ranch is in the middle of nowhere. Anyway, I did prevail, and I think the size for what we're doing is perfect.

Vanessa: Yes, the size is perfect.

The age difference between us is 21 years; it really is like this great puzzle. That's how we fit. We run our business like that. I have managed Jorma and Hot Tuna for 23 years now, and it just works. I'm not his wife when I'm managing him. He has chewed my ass out on more than one occasion, and I've had to suck it up. I have to admit I've made a bad decision or I've just assumed something, and I won't ever do that again! Laughter. It just works. I mean, our relationship with each other - and with our kids - works in pretty much the same way, in a really weird way, and in a beautiful way. I taught Jorma to be a father to his son, a son that I never had. So it works. When family works together, it's great, and when it stops working, it's not good. We haven't been presented with that yet.

Jorma: It's interesting, because I know a lot of people who work with families. It makes perfect sense, actually, if the family we are working with happens to be good at what they are doing. And Vanessa is good at what she does. There are these classic things, like I'm sure you guys have seen Spinal Tap like 1,000 times? You know, where the girlfriend gets involved and screws everything up completely? These things actually do happen. Laughter. But the thing is, if you can't trust a family member, who can you trust? When Vanessa and I first started working 
together, a lot of people didn't like it because they felt they couldn't get through to me anymore. But we've been doing it for so many years that it's not an issue anymore. In the beginning, it was like people didn't want to deal with Vanessa. I think it was because they couldn't get one over on me anymore, because nobody gets one over on her. So now I just say, "It's fine with me, but talk with my wife. I've got to go." Laughter.

Vanessa: We were lucky enough to go out on tour, before our daughter Izze came, when I was still free to travel. We worked with Columbia Artists management and they were an amazing management organization. Up to that point they had mostly dealt with classical music acts, high-level classical acts. They would do these big performing arts tours all around the world, and one of these partners came up with the idea to do guitar summits. The first guitar summit included Jorma, Kenny Burrell, Manuel Barrueco, Steve Morse, and Stanley Jordan. It was fantastic and the way they ran their organization was not how things were done in rock 'n roll.

Jorma: In fact, they don't even talk about their organization as being promoters, they talk about being presenters. It's a different headspace entirely, it really is. You might think that it's really just another name, just semantics, but it's not. It's a different headspace entirely.

Vanessa: I mean this in the most respectful way, but the rock ' $n$ roll world had been like the crazy Democrats and Columbia Artists were like the uptight Republicans. But you know what? I liked their model. There was no room for financial disaster, everything was very well organized, and what they said would happen, happened. We said to each other, "Wow! Could we run Jorma's organization the same way they are running their organization?" Going out on the road with Hot Tuna, I'd been fighting tooth and nail to try to have things be a little different, but for so long it was still like crazy Jefferson Airplane days. So when we came back from that tour, we put the brakes on. Everything changed and nobody said anything. Everybody kind of responded to the changes with, "Wow, things are working pretty good!" So that's the way we work when we are out on the road now. The business end of it is great. Before, people were hired as managers because they had a credit card! Laughter. With Jefferson Airplane, early Hot Tuna, someone could be your manager as long as they could get you into a hotel. They didn't even have to be a respectable manager but more like a muscle head to go up against some of these promoters and beat the money out of them. These things were happening! Really! Things were crazy when I first started managing this.

So now there is no more mismanagement in our organization. It works. And, for what it's worth, we have a reputation to uphold, we have kids! When you have kids, you can't be crazy rock 'n rollers anymore. You have to tone it down.

\section{INT: People talk about Fur Peace Ranch as a community. Can you describe how that works and how you've built it?}

Jorma: It's one of those things that is very hard to quantify, because you can't really plan it. You can't go into it with a plan to build the kind of community that we have here and expect that it is just going to happen. You really can't do that. But I think that one of the things contributing to the sense of community at Fur Peace Ranch is the kind of music that collectively we all love, whether it's electric or folk or whatever. It's a very social kind of music and all of the people that come here share a love for this kind of music. There are certain aspects of rock 'n roll that are utterly asocial in terms of hanging out, sharing stuff, etc. But in the wooden (acoustic) music world, and in some of the electric music world too, it's very social. It's more of a, "Wow, that was cool, show me how to do that!" Music touches us on such a primordial level. Somebody you've never met before can play something, without even verbalizing it but just playing it, and somehow that communicates something in a very profound and deep way. I think these things get shared here, a like-minded spirit that people seem to bring with them here, and as a result of this sharing they find their new best friend. It's not just a bunch of guys who can afford to buy expensive guitars! Laughter. One of the things that Chris Smithers was joking about, was that if any of the wives of the guys who come here knew how much these instruments cost, there'd be trouble at home. Most wives probably have no idea how much some of these things cost! Laughter. But it goes way beyond that. People love the same thing. People talk about the wood in your guitar, "Gosh that's beautiful." Or somebody's got an old song, something you heard when you were 16 and that you are bringing back to the group, "Gosh that was before my time." But whatever the source, it's just that transference of information, of creative information and energy, and it works.

Vanessa: With Fur Peach Ranch, we created a type of resort that nobody had ever built before. There were - and there still are - other workshops that are presented during the summer months at various colleges, but that's a very different scene from what we offer. With the college programs, students stay in dorms and alcohol is permitted and you jump from one class to another. There is almost not enough time to be part of a community; it's a different kind of community. 
Jorma: And Fur Peace is not a fantasy camp. That's not what we do. I have people say to me, "Oh, you've got a rock 'n roll fantasy camp?" No, there's no fantasy at all. Some fantastic things may happen, but this is reality.

Vanessa: Jorma's name certainly helped, because he was our draw in the beginning. When we started the Ranch, we went to Jorma's fans first and they had been just dying for an opportunity to have someone like Jorma show them "that song." And in terms of the live shows, once the Ranch got off the ground, we realized there was something special going on here and we use the live shows as a way to market and go beyond Jorma's fan base. The first camp I did without Jorma, I remember thinking, "If we can pull this off, then we're set."

Jorma: I started out as the name draw and I'm here much of the time, but not all the time. Still, we have so many great people that it doesn't depend on me always being present. We get a guy like David Lindley and people say, "Wow, David Lindley's teaching?" Not only that, but he's also going to perform a live show when he's here.

Vanessa: When we first started the concerts, there was very little music within a 50-mile radius of here. You had the bars in Athens (Ohio) and you had Memorial Auditorium on the campus of Ohio University, but this was before Stuart's Opera House in Nelsonville started operations. Once the rest of the people that wanted music and that had it in them to be a presenter or a promoter or an owner, once they saw that we were really willing to take that risk, then they opened up their own little place too. All the sudden, within five years, there was music in all sorts of places. So I called a meeting, it was kind of like a meeting of the five families. I felt like Don Corleone! I said, "I want to talk." They said, "What do you want to talk about?" And I said, "Bring your ideas, let's talk about this together." So at that meeting, we started to share our schedules and plans and we all found a way to bring in and keep music in this community. We started to help co-promote activities, sharing our flyers and other promotions. And it was great! We took a leap of faith to start it off, and then everybody else just took a leap of faith too. That's what happened. We started it and it's continued to grow.

Jorma: Athens has always had a good music scene. There's always a lot going on there. There's something for everybody. For us, it is interesting because Fur Peace Ranch is a destination, not a waypoint. We don't serve alcohol, yet almost all of our shows are sold out. The performers that play here, I tell them that these people are here to see you play. They're not here to party or talk to their friends or whatever, they are here to see you play.

Vanessa: The community that we have developed here - it's a "Field of Dreams" kind of thing. If you build it, they will come. If you offer someone something that jerks their chain, and they feel like you did it just for them, we thought maybe we can sell a season ticket for the live shows. Now I have to beat them off with a stick, I have to turn people away who want season tickets, otherwise I'd have every seat in the performance hall sold to season ticket holders. People want to be part of the scene here, because of what we're offering. It's safe. If you want to have a wild time, there are other places you can go. For me, it's very different and I am never let down. After every single camp, after every single group of students leaves, I say, "Well that will be hard to top because that was a great group of students. I made like 20 new best friends!" But then the next week comes around and I'm like, "Well, that one's going to be hard to top." And I've been doing this for 16 years. With the shows, we work like dogs, as it really is work. To successfully pull off the show, I'm constantly running. I never stop, I never stop. But when the music starts, and I get to stand in back and watch it all come together. I still pinch myself and say, "I can't believe this, it is so cool." This really connects with me personally. My dad was a country western singer and music was my life when I was growing up. I was supposed to sing when I was a kid, but I was blessed with organizational skills instead. So I got the best of all possible scenarios for myself. It's like a huge treat for me to be able to put on these live shows.

\section{INT: So where did the idea for the silo and the Psylodelic Gallery come from? And what do you hope to accomplish from that?}

Vanessa: The silo came from my Type A thought processes, which never shut off. Like I said, I'm cursed with organizational skills. That's great if I'm working for you, but I have to go to sleep with this head. I never give up thinking about another project. It's a character defect that $50 \%$ of the time turns out okay. But we were in the Catskill Mountains in upstate New York, doing a workshop at the Full Moon Resort. They had a silo near there, where they claimed to have the world's largest kaleidoscope. Instead of sitting around the resort while everyone was in class, we decided we'd go and check that out. So we headed out to Woodstock, got some coffee, and then went to see the world's largest kaleidoscope. We go in and they've got several small kaleidoscopes around there, and then they have the silo. They charge you $\$ 10$ to go in to see the world's largest kaleidoscope. The kaleidoscope itself wasn't very big, and they had these weird sawhorse-like things covered with carpet that you are supposed to lean up against while looking up at the kaleidoscope, and it was awful. A father and son back in the 60s designed the kaleidoscope, big mirrored panels, this big crazy thing. Not just a digital one projected onto a ceiling. Then the lights go down, and a person sounding like a radio announcer starts talking about America, 
and you start seeing the Indians and Plymouth Rock and the first Thanksgiving and everything, all of it with bad animation. They go through all sorts of events in history. Then they got to the 60s and they're playing the Rolling Stones and they show a pot leaf. I'm watching this and thinking, "What? That's not the 60s! This is BS!" So I'm freaking out throughout the entire show and afterwards I said to my friends, "That was an outrage! I'm going to build the world's largest psychedelic scope." The folks who were with me were looking at each other saying, "She's really lost her mind on this one!" And I said, "No, I'm not done with this." I began looking for silos and two years later, I got this fellow to sell me a silo for a ridiculously low price of under $\$ 20,000$. He said if I sent him the money in a month, he'd shave off an extra $\$ 5000$ from the price. So I called up Jorma and I said, "I bought a silo!"

I went back to my banker and said that I had changed my business plan. You know, everything has a dual purpose for me at Fur Peace Ranch, but this was just going to be a museum. Then I thought, "What am I going to do with a silo that's just a light show? One person will go, and that'll be it and they won't come back, there won't be a reason to come back." So I'm going to build a gallery in the silo, a historical gallery devoted to the psychedelic era. I verbally laid it all out and I said I'm working on the business plan, and the banker said I don't need a business plan. "What a great idea," he said. "I believe you can make it work." I told him, "Great, so this is what I'm going to need." He said okay, so I got a local architect to help with the design, a couple of local farmers to put up the silo, and a construction friend who did everything on verbal spec. The woodwork inside is just awesome! It's like a boat. We changed things as we went along and structurally some aspects changed, but all of the inside was intended to all be an exhibit, even the stairs inside were intended to be part of the exhibit.

Thank God for Jorma, who never threw anything out! Laughter. When I first met him, his ex-girlfriend told me, "You know you've married a used car lot, don't you?" Jorma had like nine cars in the driveway and certainly not all were nice vehicles. Then he opened his garage, and it was filled with crate after crate of stuff from his whole life. Posters and clothes, his first wife's artwork, all sorts of things. It took me 15+ years to go through it all. I didn't even know at the time that I would do a museum. Then we moved it all here when we came to the Ranch, and I just started cataloging everything. My assistant Ally, a French history major from Ohio University who is more Type A than me, she said this will be her first show. I remember talking with her about the quote wall, saying, "Okay, I want to hear the voices, and I want them to each be in a different type font because everybody has a different voice. And I want politicians and writers and musicians!" I was like that crazy owner, the person that when they hire the contractor, the contractor rolls his eyes and goes, "Oh, my God." Well, I was that person. But the contractor was great. He's not a music person, he was completely not starstruck at all. He likes to build things, and he gave me this amazing gallery space to present the voices of the 60s, and there are no pot leaves and there are no Rolling Stones in there. And that's how it all started: a result of my outrage that somebody would actually suggest to tourists at a tourist destination that the 60 s were pot leaves and the Rolling Stones. We just couldn't have that.

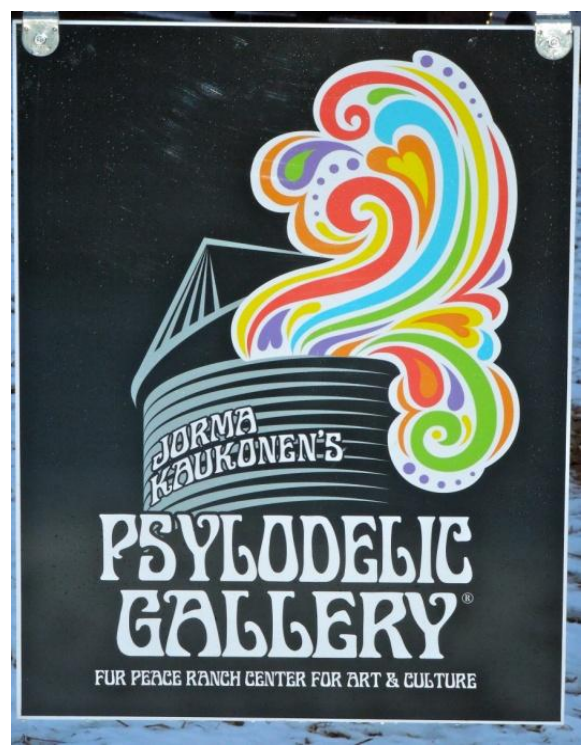

Figure 3. Psylodelic Gallery sign at Fur Peace Ranch 


\section{INT: What do you hope to accomplish with the Psylodelic Gallery?}

Vanessa: I did it. What happened was that I created a gallery space that will educate this new generation about the 60s and that will also jerk the chain of the generation that remembers it and lived through it.

Jorma: And obviously, we hope to snag some people off the highway, and we do that sometimes. They're not beating a path to our door yet, but they do show up. I travel on the road all the time, and I'm a big fan of roadside America, so my metaphor for this is that it's a heck of a lot more interesting than the world's largest ball of twine! Laughter.

Vanessa: It's about an education, it's about telling a story. You know, the Rock 'n Roll Hall of Fame is wonderful, and their exhibits are amazing. But this is a different trip. It's busting out of the seams. I can't put everything in there that I want to.

Jorma: The Rock 'n Roll Hall of Fame is about rock 'n roll. But this is about more than just the music. I know it's hard to imagine, but not everybody was at Woodstock. Laughter.

Vanessa: It's about the voices of that very small window in time called the psychedelic era. It's told in the clothes, in the war, in the music that we played, in the instruments that we collected, in the books that we read and the art that we loved. Every one of those voices is attached not merely to each of the quotes, but also to Margaret's artwork and to Wavy Gravy's amazing story about his sleeping bag. It's attached to the jewelry that they wore, to the controversial jewelry. There's a piece in there that happens to look like a swastika; there's a huge story attached to that. The Wes Wilson concert posters we have there, they have a story to tell. It was all a way for people to understand, it's their voice.

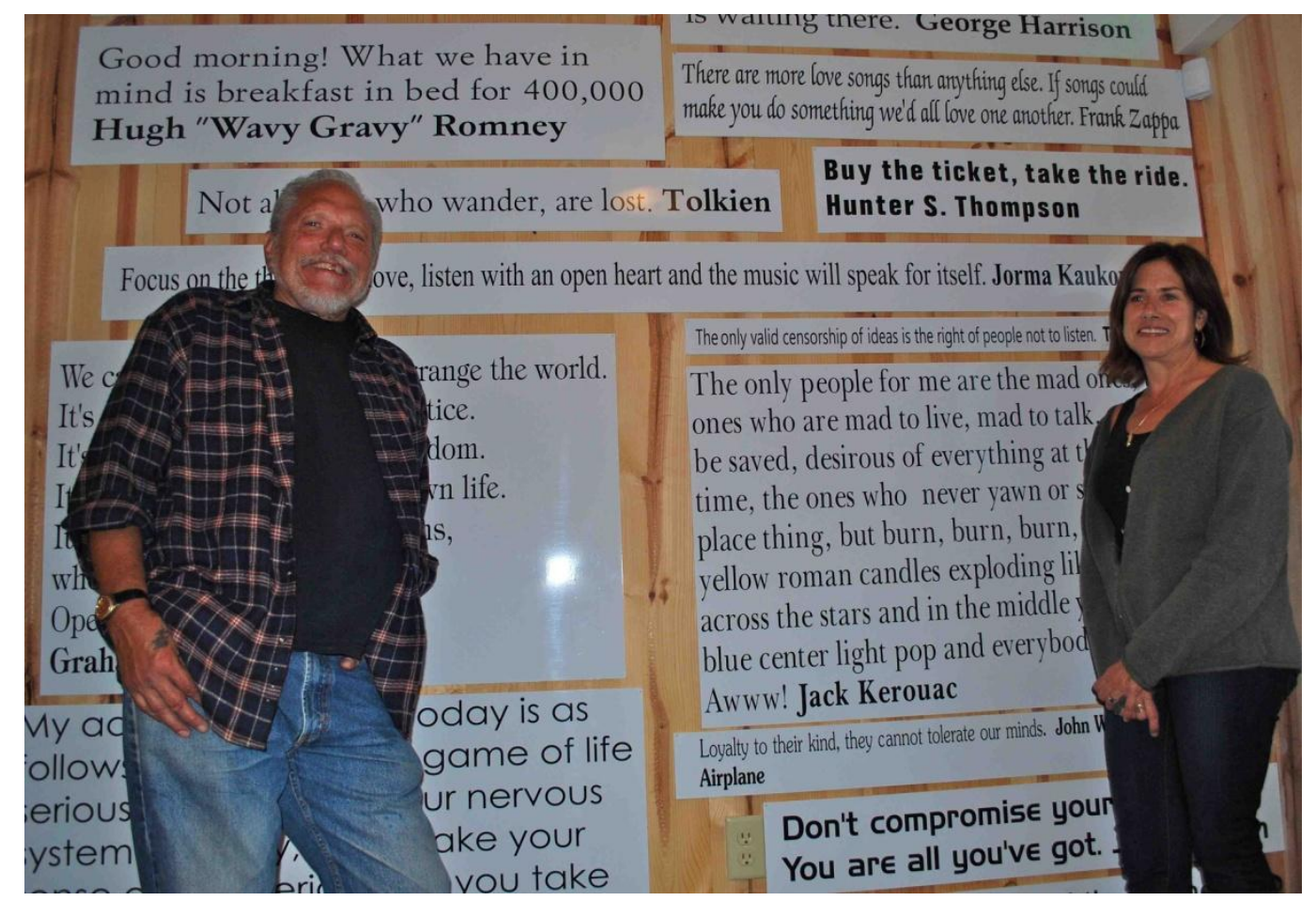

Figure 4. Jorma and Vanessa Kaukonen in front of the Quotations Wall in the Psylodelic Gallery 


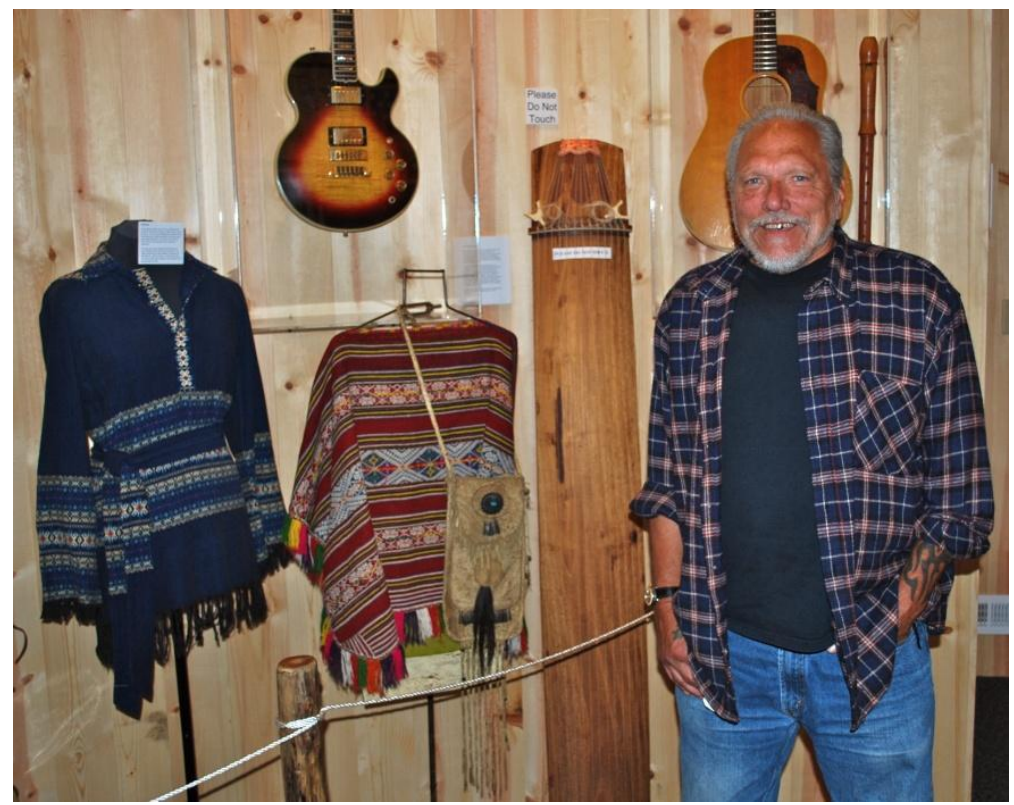

Figure 5. Jorma Kaukonen in front of an exhibit of musical artifacts in the Psylodelic Gallery

\section{INT: What are your plans for the future of Fur Peace Ranch?}

Jorma: That's a good question. At this point, we don't think we want to get any larger. I like the fact that you can actually remember everyone's name by the time the weekend is over. So I guess we're just kind of riding the wave right now. We want to continue bringing great talent for teaching, offer great concerts, keep the Psylodelic Gallery going with good exhibits, and we would like to be a place that people will say, "If you're driving through southeastern Ohio, you should stop by the Fur Peace Ranch and check it out."

Vanessa: We've been riding the wave since we opened the doors. But we don't want to get bigger. We really don't want to be any bigger. One of our students, years ago, offered me the opportunity to build another Fur Peace Ranch on the West Coast. I'm like, how am I going to be able to be there with a cup of coffee waiting for my students when I have to be here? That's when the idea first came up for doing workshops on the road. We can actually go to other regions and offer the workshops.

Jorma: You can't franchise the Ranch. You just can't franchise this thing. It wouldn't work. You have to come to Darwin, Ohio, if you want to experience this. Laughter.

Vanessa: The cool thing for us is that once I learned that I can run this without Jorma being here, without him physically being here all of the time, then I knew this could be a success. In the beginning we were asking people to come here to teach. We had no history, there was no reputation for Fur Peace Ranch. We were asking people to come and teach, and they did not even know if our checks would cash! I can imagine what it must have been like for the artists when we called them!

Jorma: Well, in the beginning, I had to shame my friends into coming. Laughter.

Vanessa: Now we don't even have to call. They call us. Now I can't fit in everybody who wants to teach. And everybody wants to teach! Big names draw, we still believe that. But not every name that draws is a good teacher. So, as disappointed as we were with a couple of teachers we have had - people who were not comfortable breaking down the teaching approach to their songs ...

Jorma: You know, in the old days when we learned to play, the people I learned from did not break it down. They just played the music for you, and said, "Here's how it goes." Then we worked on it and we came back and said, "How's this?" And they'd say, "You suck!" Laughter That's exactly the way it was. My musical muse has been the Rev. Gary Davis and for the same reason that I like Eric Clapton more than Jimi Hendrix. Because it's more orderly and I can comprehend a little bit better what is going on. When I'm playing acoustic guitar, I know what I'm doing, I know exactly what I'm doing. I can show people what I am doing, I can explain what is going on. With some of these other guys, they're old school, they're brilliant, but they've never really thought about it so they can't really verbalize what they're doing. 
Most of the people who come here as students are not prepared to learn the way we did, to just hang out with a musician, watch him, pester him, and learn how to play that way. They don't have the ability to do that. Not that you can't learn it, but they like to have things tabbed out, they don't have the ear training. Besides, they only have four days here in which to learn. I'm not critical of modern learning methods. There's so much good stuff on YouTube and gadgets that allow you to slow stuff down without changing riffs. Like our site, breakdownway.com. Laughter. You know, it's all good, having stuff like that, because it's a different time now than when I learned to play. So what we need in teachers here are people who can fit into our view of how the workshops should run. We don't tell people how to teach. Everybody does it differently. For example, I'm very anecdotal about how I teach. A lot of other people write their stuff out, but I don't do that. But in any case, we need people that can actually communicate and help the students feel comfortable without feeling that they only have four days and they just don't have time to actually grasp what's going on. This way, they get to take notes home, they get to take recordings home, things have been explained in a way that can be replicated once they get home, and so forth. That's just the way it is here at the Ranch. You get to go through several songs in a weekend, at the very least. It's such a learning experience.

I have taught guitar since back in the very early 1960s, since the first years of the Airplane. I made more money teaching guitar than I did in the band. In fact, I made no money in the band, so it was easy to make more money than that! Laughter. When we first started doing workshops at the Ranch, we would do like 17 songs in a weekend. It was kind of the approach where we said, "Okay, we got that one down, let's do another one." We don't do that anymore. We try not to do more than four songs, and we make them all accessible, and we know people go home with a song. So they have something to show for their time once they get home, when someone asks them, "What did you learn at the workshop?" Not just some stupid little lick that only means something to you. "Yeah, yeah, that's great, but can you play a song?" "Well, I didn't learn any songs, I just learned a lick." Instead, they go home from our workshops with a couple of songs they can play. We don't do 17 songs in a weekend anymore.

INT: You two are a great team. There's going to come a time where, for one reason or another, you will remove yourself from this business. Will it continue on?

Jorma: That's a good question. I mean, nothing lasts forever. We all know that. People say to me, "are you ever going to retire?" And I say, "retire from what?" But you are right, at some point things will change. So I guess the answer is, we don't know.

Vanessa: We are really just living for the moment. Yes, I know what my schedule is next week. And I know which of my staff will be here in the next couple of weeks and what they will be doing, and I know what my workshop and music schedule is going to be for the coming season.

Jorma: From the point of view of creating some sort of enduring monument to oneself, you'd like to see it getting to 100 years. People saying, "Yeah, we're going to Fur Peace Ranch, it's been around for 100 years." That's probably not going to happen, but it might. Who knows?

Vanessa: We can really get anal about it, and say we'll leave it in a trust and say it has to be run in this way or that, and that we're cashing out and going to Tahiti! Laughter. But we're not going to do that.

For some people, at the first sign of trouble with their business, they'll sell it. Not me. I almost lost my shirt the first year. I wasn't charging enough. I've made every mistake an owner can make. And I thought, "Oh my God, I just signed away my life. Why did I go to the bank for financing? Why didn't I use my own money?" And I just remember that I believed that this would work. It is working. But 2008 and 2009 were excruciatingly horrible years in the financial world. And my 97\% return rate among attendees? Some of these people were losing their jobs at the time. We have a broad spectrum of backgrounds among the people who come here. We've got blue-collar workers and we've got white collar. $60 \%$ of them are lawyers, doctors, people working in finance, and many of the financial people were losing their jobs.

Jorma: When the stuff really hit the fan, we had guys coming in saying, "I just lost my job and I figured, screw it, I'm going to Fur Peace Ranch!" Laughter. But, over the next year or so, when the reality of all this set in, one of the things that happened to us was that we could no longer be as adventuresome with our teachers. We had been taking a lot of risks with really interesting teachers, but it didn't matter. We had maybe six teachers here, and it didn't matter if all the classes were full or not because at that time we could afford to run things that way. But with the financial realities of 2008 and 2009, we couldn't really run things like that any more.

Vanessa: We bring in the teachers that we know will sell out, that are going to offer a great class. But 2011 and 2012 were great years for us. We weathered the financial crisis and its aftermath, though it was a little scary at 
times. I didn't fire anybody; everybody is still here, I still paid everybody. As a matter of fact, we put a store up in the shopping mall because I thought, "Well, we weathered that, so I'm going to build a new store, and a silo too!" Laughter. And that's saying that if you're going to lose, lose big. You have to take a risk if you want to be different. We're unique! You can't stop being unique or somebody else will come along and replace you. You can't stop taking risks. You just can't.

\section{INT: What would be your advice to someone who wanted to go into the music field?}

Vanessa: Don't quit your day job!

Jorma: Actually, I would not give that advice, unless it was a family member! Laughter.

Vanessa: You did! You did! Remember that kid, that young budding guitar player, one of the baggers at the grocery store? He was going to Nashville and you were trying to get through the grocery line. Remember that kid? And he said to Jorma, "I'm going to Nashville. Do you have any advice for me?" I thought, "Oh shoot, Jorma, don't say it. Don't say, 'don't quit your day job, kid!’” But he did! He said it! Laughter.

Jorma: But I was joking because the real advice is that you have to love it. You have to be prepared to give up your day job. You have to be prepared to sleep on people's couches, to travel in vans and sleep in your van, to share hotel rooms and do all kinds of stuff. You need to love it and to have no expectations. You will never be disappointed then!

Vanessa: You also have to put legs on your prayers. If this is what you want, then you have to work for it. Yes, sometimes lucky breaks happen. A lucky break happened with the Jefferson Airplane!

Jorma: Exactly! Lucky breaks happen all the time. To be honest with you, that's really where the rubber meets the road. But if you're not out there doing it, you can't have a lucky break. You need to be out there doing it in order to give an opportunity for that lucky break to happen. At some point, somebody who will matter in your life needs to hear you and go, "Yeah." You need to keep putting it out there.

Vanessa: If you want to succeed - well, look at a lot of the young artists who came up, back in the 50s and 60s. There were a lot of one hit wonders. We remember the song, but can't tell you who did it because we never heard from them again, for whatever reason. But if it's what you want, anyone can change a career. I don't think Jorma is going to change his career at this point, but we're not getting rich with the Fur Peace Ranch. It's working, but we cannot retire. We put much more into this than we actually get back. So after 16 years, we're still here. If I quit building things then maybe it would be different ... laughter ... but that's the way it is. It's like, okay, expenses are going up, and I don't ever really raise my fees enough to cover what's going on. But it pays for itself.

Jorma: And I need to tour, not just because that's how we support ourselves. I mean, that's my job, and I love to do it. I would not be happy if I wasn't touring.

INT: Knowing what you know now, if you could reverse course, would you have made a different decision 17 years ago and not created the Fur Peace Ranch?

Jorma: No, not at all. No. You've got to do something and what could be more fun than this? As long as when you put your elbows out you don't touch wood, it's good. Laughter.

\section{References}

Balkin, N. (2014, January 29). Berklee Launches Institute for Creative Entrepreneurship. Boston, MA: Berklee College of Music. Retrieved from http://www.berklee.edu/news/berklee-launches-institute-creative-entrepreneurship-panos-panay-namedfounding-managing

Berklee College of Music. (2013). Rethink Music: New Business Models in the Music Industry. Boston, MA: Berklee College of Music. Retrieved from http://rethink-music.com/wp-content/uploads/2013/06/RMVFinalEdit.pdf

Covert, A. (2013, April 25). A decade of iTunes singles killed the music industry. CNN Money. Retrieved from http://money.cnn.com/2013/04/25/technology/itunes-music-decline/index.html

Pollstar. (2014, January 10). Pollstar's 2013 North American Numbers. Retrieved from http://www.pollstar.com/news_article.aspx?ID=808976

The Economist. (2007, June 5). The music industry: A change of tune. Retrieved from http://www.economist.com/node/9443082/+DOI 


\section{Copyrights}

Copyright for this article is retained by the author(s), with first publication rights granted to the journal.

This is an open-access article distributed under the terms and conditions of the Creative Commons Attribution license (http://creativecommons.org/licenses/by/3.0/). 